\title{
LĖTINE OBSTRUKCINE PLAUČIŲ LIGA SERGANČIŲ LIGONIŲ REABILITACIJA
}

\author{
DOVILE் KRYŽIŪTE், JOLITA VEDRICKAITÉ \\ KMU PULMONOLOGIJOS IR IMUNOLOGIJOS KLINIKA
}

Reikšminiai žodžiai: lètinè obstrukcinè plaučiu liga (LOPL), reabilitacija, kūno masės indeksas (KMI), kineziterapija. Santrauka. Pagrindiniai plaučių ligų reabilitacijos tikslai yra lengvinti simptomus, gerinti paciento gyvenimo kokybę ir skatinti fizinį bei emocini aktyvumą. Sprendžiamos ir kitos problemos: fizinio krūvio toleravimo mažejimo, santykinès socialinės izoliacijos, nuotaikos sutrikimų, ypač depresijos, raumenų nykimo ir kūno masės mažejimo. Didžiają dali pacientų, kuriems skiriama pulmonologinè reabilitacija, sudaro ligoniai, sergantys lètine obstrukcine plaučių liga (LOPL). Straipsnyje apžvelgiamos naujausios Amerikos torakalistų bei Europos pulmonologų sajungos parengtos pulmonologinès reabilitacijos rekomendacijos.

\section{IVADAS}

Fizinė ir reabilitacinė medicina yra medicinos šaka, atsakinga už specializuotą pagalbą žmonèms, turintiems kokią nors fizinę negalią. Europoje ji pripažinta Europos medicinos specialistų sąjungos (UEMS) ir apibrèžiama kaip savarankiška medicinos specialybè, galinti pagerinti žmogaus fizines ir pažinimo funkcijas, aktyvumą, gyvenimo kokybę, modifikuoti asmeninius ir aplinkos veiksnius. Pastaruoju metu itin suaktyvèjusị domèjimąsi pulmonologine reabilitacija lėmė didejjantis besikreipiančių pacientų skaičiaus ir gerëjantis lètinių kvejpavimo takų ligu patofiziologijos ir pritaikymo pulmonologineje reabilitacijoje supratimas, dèl vis dažniau atliekamų mokslinių, klinikinių bandymų.

Kaip žinia, LOPL yra viena labiausiai paplitusių ligų, lemianti netektis ir ekonominius nuostolius.

Pasaulio sveikatos organizacijos duomenimis, lètine obstrukcine plaučių liga serga maždaug 14 proc. pasaulio gyventojų. Pernai pacientų skaičius siekè net $600 \mathrm{mln}$., daugiausia vyresnių nei 40 metų. LOPL daugelyje šalių užima 4-6-ąją vietą tarp dažniausių mirties priežasčių. Mirtingumas nuo jos yra keliasdešimt kartų didesnis negu nuo astmos. Ivairiose šalyse nuo LOPL per vienerius metus miršta 100-400 vyrų iš 100 tūkst. ir apie 80 moterų iš 100 tūkst. Sergamumas LOPL ir mirtingumas nuo jos kasmet dideja. LOPL yra viena dažniausių laikinojo nedarbingumo ir invalidumo priežasčių. Vien JAV ja serga daugiau nei $15 \mathrm{mln}$. žmonių. Lietuvoje pirmą kartą pripažintų invalidais dèl lètinio obstrukcinio bronchito skaičius 2006 m., palyginti su 1996 m., padidejo 19,6 proc., o darbingo amžiaus asmenų - net 27 proc.
Taigi nenuostabu, kad 2006 m paskelbtame Amerikos torakalistu sąjungos ir Europos pulmonologu sąjungos bendrame susitarime numatytos būtent lètinėmis plaučių ligomis sergančių pacientų reabilitacijos gairès, ypatingą dèmesị skiriant lètine obstrukcine plaučių liga sergantiems pacientams.

\section{APIBRÉŽIMAS}

Kvėpavimo sistemos ligomis sergančių ligonių reabilitacija - akivaizdžiai įrodytas daugiafunkcis ir visapusis poveikis letinėmis kvėpavimo ligomis sergantiems pacientams, kuriems liga pasireiškia simptomais ir riboja kasdieni aktyvumą.

Kvėpavimo sistemos ligomis sergančių ligonių reabilitacija, apimanti individualu gydymą, yra skirta simptomams palengvinti, nedarbingumui sumažinti, funkcinei, psichologinei būklei optimizuoti bei sveikatos priežiūrai skirtoms léšoms mažinti stabilizuojant ar stabdant sisteminius ligos požymius.

\section{FIZINIO KRŪVIO NETOLERAVIMAS SERGANT LOPL}

Svarbiausias veiksnys ribojantis lètinėmis kvèpavimo ligomis sergančių ligonių aktyvumą yra fizinio krūvio netoleravimas. Pastaruoju metu daugèja tyrimų, kuriais nustatomi fizinio krūvio netoleravimo mechanizmai, tačiau daugiausia dèmesio skiriama būtent asmenims, sergantiems lètine obstrukcine plaučių liga. Pagrindi- 
niai simptomai, ribojantys fizinị krūvị sergant lètine obstrukcine plaučiu liga, yra dusulys ir/ar nuovargis, kuriuos gali sukelti kvėpavimo organų sistemos, duju apykaitos, periferinių raumenų funkcijos, širdies veiklos sutrikimai. Dažnai pabrěžiama, kad bloga nuotaika ir depresija turi įtakos simptomų suvokimui, vadinasi, gali lemti fizinio krūvio netoleravimą, tačiau tiesioginis ryšys tarp paciento emocinès būklès ir fizinio krūvio toleravimo dar nèra gerai ištirtas.

Kvėpavimo organų sistemos sutrikimai. Fizinio krūvio metu sergant LOPL pablogëja dujų apykaita, dideja ventiliacijos poreikis, dažnëja kvėpavimas, didèja krūvis kvèpavimo raumenims (periferiniu raumenu disfunkcija), dèl to vèliau išryškèja kvejpavimo diskomforto suvokimas.

Dujų apykaitos sutrikimai. Hipoksija fizinio krūvio toleravimą gali riboti ir tiesiogiai (stiprèja plaučių ventiliacija, nes daugèja periferinių chemoreceptorių), ir netiesiogiai (skatina pieno rūgšties gamybą). Padidejjęs pieno rūgščių kiekis turi įtakos raumenų veiklos nepakankamumui ir plaučiu ventiliacijos stiprèjimui, o kad šie pokyčiai būtų normalizuoti, dideja $\mathrm{CO}_{2}$ gamyba.

Širdies veiklos sutrikimai. Širdies ir kraujagysliu sistema yra veikiama lètinès plaučių ligos dèl daugelio priežasčių. Pagrindinè ta, kad dèl padidejusio plaučių kraujagyslių pasipriešinimo hipertrofuoja dešinysis širdies skilvelis, ryškejja jo funkcijos nepakankamumas, itakos turi ir tiesioginis kraujagysliu pažeidimas, hipoksinè vazokonstrikcija. Vèliau pasireiškęs kairiojo skilvelio nepakankamumas lemia mažesni širdies pajègumą, o miokardui hipertrofavus ar išsiplètus prasideda tachiaritmijos. Be to, pats nejudrumas gali bloginti širdies ir kraujagyslių būklę, o dèl to ilgainiui dar labiau mažèja fizinio krūvio toleravimas.

Skeleto ir raumenų sistemos funkcijos sutrikimas. Sergant lètine obstrukcine plaučių liga vystosi šie patofiziologiniai pokyčiai: mažèja ir riebalų, ir neriebalinė kūno masè, tačiau santykinai riebalų masès organizme išlieka daugiau; raumenyse mažejja I tipo skaidulų bei skersinių skaidulu plotuc, todèl vèliau raumenys atrofuojasi, blogeja ir kraujotaka juose, nes silpnèja kapiliaru ryšys su raumenu skersiniu skaidulu plotais. Svarbu ir tai, jog sutrinka raumenu metabolinè veikla: mažèja oksidacinių enzimų kiekis (3-hidroksiacil-CoA dehidrogenazès, citochromo $C$ oksidazès ir kt.), didejja citochromo $\mathrm{C}$ oksidazès aktyvumas esant hipoksijai; sutrinka metabolizmas ramybeje (po fizinio krūvio): mažeja ląstelès $\mathrm{pH}$, daugejja laktatų ir inozino monofosfato, mažèja glikogeno. Taip pat gali atsirasti ar padaugèti uždegimo žymenų skeleto raumenyse, dideja oksidacinis stresas skeleto raumenyse po fizinio krūvio, tenkančio keturgalviui šlaunies raumeniui.

Kvèpavimo raumenų funkcijos sutrikimas. Pacientų sergančių lètine obstrukcine plaučių liga diafragma prisitaiko prie ilgalaikès perkrovos ir yra atsparesne nuovargiui. Pokyčiai ryškèja sparčiau nei spejja prisitaikyti skeleto raumenys. Atsiranda hiperinfliacija, kuri sutrikdo kvėpavimo raumenų veiklą. Kvẻpavimo raumenų silpnumas savo ruožtu sąlygoja hiperkapniją, dusulį, naktinę desaturaciją ir blogina fizinio krūvio toleravimą.

Fiziniai pratimai yra svarbiausia pulmonologinès reabilitacijos dalis bei geriausias būdas pagerinti lètine obstrukcine plaučių liga ir, manoma, kitomis lètinèmis plaučių ligomis sergančių ligonių raumenų funkciją vei- kiant skeleto ir raumenų funkcijos sutrikimą lemiančius minètus patofiziologinius mechanizmus. Atliekant fizinius pratimus, didèja neriebalinė kūno masè (kartu vartojant maisto papildus), raumenyse daugèja skersiniu skaidulu plotų, stiprèja kapiliarų ryšys su raumenų skersinių skaidulų plotais, didèja oksidacinių enzimų kiekis, mažejja laktatu, padaugejja oksiduoto glutationo. Be to, pagerëjus oksidaciniams procesams ir raumenų darbingumui, mažèja alveolinè ventiliacija, o tai savo ruoštu lemia dinaminès hiperinfliacijos, kartu ir dusulio mažejimą.

Taigi fiziniai pratimai reikalingi lètinèmis kvėpavimo ligomis sergantiems asmenims, kurie blogiau toleruoja fizinị krūvị, patiria dusuli ar nuovargị ir praranda kasdienị aktyvumą. Dar daugiau, išmokus daryti fizinius pratimus gali sustiprèti pacientu motyvacija, pagerèti nuotaika, palengvèti ligos simptomai, pagerèti širdies ir kraujagysliu sistemos funkcija.

\section{PACIENTŲ ATRINKIMO REABILITACIJAI PRINCIPAI}

Pulmonologinè reabilitacija dažniausiai skiriama lètine obstrukcine liga sergantiems pacientams, kurių didžiausia problema - mažejjantis svoris ir nykstantys periferiniai raumenys (šie pokyčiai nustatomi apie 30 proc. ambulatorinių LOPL pacientų). Reabilitacija gali būti sèkmingai taikoma ir pacientams, ruošiamiems transplantuoti plaučius ar po transplantacijos. Rečiau reabilitacija taikoma sergantiems astma, bronchektazèmis, cistine fibroze, retai - sergantiems intersticinėmis plaučių ligomis. Reabilitacija nerekomenduojama ligoniams, kuriems yra deguonies terapija nekoreguojama hipoksemija, sergantiems nekontroliuojama gretutine psichikos ar širdies liga, rūkantiems, nesuprantantiems reabilitacijos prasmès, neturintiems motyvacijos ir/ar nenorintiems bendradarbiauti su reabilitacijos komanda. Prieš pradedant reabilitacijos programą, pacientai testuojami, j̇vertinama kvėpavimo funkcijos nepakankamumas ir gretutinès ligos (ypač širdies ir kraujagyslių sistemos patologija), galinčios turèti įtakos saugumui atliekant fizinius pratimus, fizinio krūvio toleravimui ar ji riboti; atrankos tyrimų rezultatai (spirometrija, veloergometrija (nustatant $\mathrm{Vo}_{2} \max$ ), $\mathrm{SpO}_{2}$, dujų difuzijos tyrimas, kūno pletizmografija, rankų jègos matavimas dinamometru, keturgalvio šlaunies raumens jègos matavimas, kvėpavimo raumenų jègos įvertinimas, 6 min. ejimo mėginys ir kt.). Gyvenimo kokybè ivertinama pacientui užpildžius Šv. Jurgio ligoninès kvèpavimo anketą.

\section{PULMONOLOGINĖS REABILITACIJOS PRINCIPAI}

Kvėpavimo sistemos ligonių reabilitacija apima pagalbos priemones, padedančias rūpintis lètine kvėpavimo liga sergančiais pacientais visą gyvenimą, ir garantuoja aktyvu paciento, šeimos ir gydytojo (sveikatos priežiūros darbuotojo) bendradarbiavimą. Reabilitacijai priskiriama pagalba metantiems rūkyti, pacientų būklès ivertinimas, fiziniu pratimų atlikimas, pacientu mokymas, mitybos korekcija ir psichosocialinè pagalba. Reabilitacija vykdoma ligos remisijos metu, idealiausia po LOPL paūméjimo. Su pacientu dirba reabilitacijos komanda: pulmonologas, fizinès ir reabilitacinès medicinos slaugytoja, kineziterapeutas, psichologas, dietologas, socialinis darbuotojas, ergoterapeutas. Reabilita- 
cijos tikslai ir programos (fizinio krūvio) intensyvumas, be abejonès, kiekvienam pacientui numatomi individualiai. Pulmonologinès reabilitacijos sudedamosios dalys:

- Fiziniai pratimai.

- Mokymo programos:

- šeimos ir paciento mokymas;

- mitybos programos (iskaitant svorio kontrolę);

- metimas rūkyti (jei pacientas rūko);

- imunizavimas ir apsauga nuo infekcijos.

- Medikamentinis gydymas:

- inhaliatoriai (beta 2 agonistai ilgo ir trumpo poveikio, gliukortikosteroidai ir kt.);

- atsikosèjimą gerinantys ir kt.;

- oksigenoterapija.

- Terapijos technikos apmokymas:

- inhaliavimo;

- oksigenoterapijos;

- namuose naudojamų inhaliatorių, deguonies aparatų, deguonies kondensatorių.

- Fizinès terapijos:

- kvėpavimo mankštu apmokymas;

- atsipalaidavimo pratimų apmokymas.

- Užimtumo terapija:

- kasdienès veiklos ivertinimas.

- Psichosocialinė reabilitacija.

- Profesiné reabilitacija.

\section{FIZINIU PRATIMU (REABILITACIJOS) PROGRAMOS VYKDYMAS SERGANT LE்TINE OBSTRUKCINE PLAUČIŲ LIGA PASAULYJE IR LIETUVOJE}

Reabilitacijos programa skiriama dažniausiai 2-6 mėnesiams (ne mažiau kaip 20 treniruočių po 2 val. 3 kartus per savaitę), pradedant nuo daugiau kaip 60 proc. maksimalaus paciento pradinio fizinio krūvio. Programos eigoje ir pabaigoje atliekami anksčiau minèti tyrimai, vertinamas fizinio krūvio toleravimas bei gyvenimo kokybès pokyčiai.

Nèra abejonių, kad ilgesnès trukmès reabilitacijos rezultatai geresni negu trumpesnès. Ambulatoriniams pacientams rekomenduojamas treniravimasis du tris kartus per savaitę septynias savaites yra daug naudingesnis nei keturių savaičių. Rezultatai, pasiekti per dvidešimt užsièmimų bus geresni nei po dešimties.

Pacientams dažniausiai rekomenduojama atlikti fizinius pratimus po dvi valandas mažiausiai tris kartus per savaitę prižiūrint specialistams, alternatyva galètų būti du užsiemmimai per savaitę prižiūrint specialistams ir vienas ar daugiau užsièmimų savarankiškai namuose. Vienareikšmiškai teigiama, kad vienas užsièmimas per savaitę neduoda laukiamos naudos. Mažo intensyvumo programos yra irgi ne tokios efektyvios kaip didesnio intensyvumo. Veiksmingiausi - labai intensyvūs (beveik maksimalūs konkrečiam žmogui) pratimai, tačiau jų dažnas ligonis nepajejgus atlikti dèl ligos sunkumo, simptomų, ligos paūmejjimų ir motyvacijos stokos.

Prieš fizines treniruotes būtina atlikti kvèpavimo mankštą ir raumenų apšilimą. Toliau atliekamais fiziniais pratimais daugiausia treniruojamos apatinès galūnès - tam naudojamas bègtakis ar veloergometras, ìvairūs treniruokliai. Yra ir viršutinėms galūnėms treniruoti skirtas veloergometras, naudojami svarmenys, elastinès gumos. Rankų raumenų treniravimas sumažina dusuli judinant viršutines galūnes ir ventiliacijos pokyčius keliant rankas.
Ištvermès treniruotėms naudojami dviračiai ar ejjimo pratimai. Optimali yra ilga (daugiau negu $30 \mathrm{~min}$.), didelio intensyvumo treniruotè. Jei ligoniui sunku, treniruotes galima suskirstyti mažesniais intervalais su poilsio ar mažesnio intensyvumo fizinio krūvio pertraukèlèmis. Jègos stiprinimo treniruotès efektyvios raumenims stiprinti ir ju masei didinti. Šie pratimai paprastai geriau toleruojami nei aerobiniai, rečiau būna dusulys. Geriausias metodas - derinti ištvermès ir jègos stiprinimo treniruotes.

Kiek mažiau veiksmingi esti fiziniai pratimai, skirti ikvejpimo ir iškvejpimo raumenims lavinti (diafragminis kvèpavimas, kvèpavimas pro sučiauptas lūpas, forsuoti iškvėpimai)

Pacientai fizinius pratimus turètu atlikti aktyviai patys. Tačiau jei yra labai nusilpę, pratimai atliekami pasyviai (pvz., naudojami specialūs dviračiai, kurios galima pritaikyti gulintiems ligoniams, ar taikoma elektrinè raumenuc stimuliacija).

Papildomai fizinių pratimų metu pro kaniulę ar katerị iš nešiojamų deguonies balionų skiriama deguonies tiek esant nuolatinei hipoksemijai, tiek atsirandančiai fizinio krūvio metu sergant lètine obstrukcine plaučių liga padeda pasiekti didesnị krūvio intensyvumą. Per treniruotes reikia stebèti ligonio arterini kraujo spaudimą, širdies susitraukimų dažnị.

Iš fizioterapijos procedūrų rekomenduojama tik elektrinè raumenų stimuliacija (diafragmos raumens, periferinių raumenų). Kitų aparatinių fizioterapinių priemoniu efektyvumas ir nauda neirodyta.

Jei paciento kūno svoris per mažas ar per didelis, turi būti užtikrinta tinkama mityba: skiriamas reikiamas maisto kalorijų kiekis, baltymų kokteiliai (jei reikia). Diskutuojama dèl mažų dozių anabolinių steroidų skyrimo esant labai mažam KMI ir atvirkščiai augimo hormono esant per dideliam svoriui.

Šiuo metu Lietuvoje vykdoma pulmonologinè reabilitacija skiriama $\mathfrak{i}$ du etapus. Pirmo etapo reabilitacija taikoma pacientui gydantis stacionare ar ambulatoriškai, praèjus ar sumažèjus LOPL paūmèjimo požymiams. Tolesnẻ antro etapo reabilitacija vykdoma reabilitacijos įstaigoje - 20 lovadienių. Reabilitacijos programa grindžiama fizioterapinèmis procedūromis bei kvépavimo mankštomis, neskiriamas pakankamas fizinis krūvis raumenims, neteikiama pagalba norintiems mesti rūkyti. Tai pat pacientai mokomi, sprendžiamos psichosocialinès problemos.

\section{PULMONOLOGINĖS REABILITACIJOS NAUDA}

Pulmonologinè reabilitacija pagerina fizinio krūvio toleravimą, ištvermę, kvėpavimo ir kitų periferinių raumenų darbą, lètinėmis plaučių ligomis sergančių ligoniu gyvenimo kokybę, sumažina nerimą ir depresiją, susijusią su lètinėmis plaučių ligomis, pagerina pacientų psichosocialinę adapatciją, sumažina hospitalizavimo dažnumą ir ligoninejje praleistų dienų skaičių, pailgina pacientų gyvenimo trukmę, todèl naudinga ir ekonominiu požiūriu.

Dauguma klinikinių tyrimų, skirtų įrodyti pulmonologinès reabilitacijos efektyvumą, yra atliekama su LOPL pacientais. Klinikinių tyrimų duomenimis, pacientų, kuriems taikyta pulmonologinė reabilitacija, mirtingumas yra mažesnis: nuo 1 metų iki 18 mèn. mirtingumo rizika reabilitacijos grupeje buvo 7,8 proc. (23 pacientai iš 315 
mirè), o kontrolinèje - 9,9 proc. (28 pacientai iš 283 mirè). JAV atliktas klinikinis tyrimas rodo, kad per šešerius metus po taikytos pulmonologinès reabilitacijos gyvenimo trukmė ilgesnè 11 proc.

Be abejo, apžvelgus literatūrą, pastebima, kad po pulmonologinès reabilitacijos smarkiai pagerejja LOPL ligoniu gyvenimo kokybè. Klinikiniu tyrimu, kurio metu 24 pacientai iš 31 , itraukti i 6 savaičiu stacionarinę reabilitaciją, nustatyta, kad gyvenimo kokybė ir fizinis pajègumas buvo daug geresni dvi savaites po išrašymo iš ligoninès, o 11 pacientu iš $24-$ šešis mènesius. Gyvenimo kokybẻ pagerejjo iki 18 mẻn. tęsiant reabilitaciją ambulatoriškai.

Australijoje atliktas šešerių metų tyrimas, kuriame tirti 78 pacientai, ịtraukti $\mathfrak{i}$ ambulatorinę reabilitaciją, rodo, kad pulmonologinè reabilitacija pagerina fizinio krūvio toleravimą, sumažina hospitalizavimo ir ligoninèje praleistų dienų skaičių. Nustatytas ryškus 6 minučių èjimo méginio rezultatu pagerèjimas: 404,2 +/$114,6 \mathrm{~m}$ iki 439,6 +/- 115,0 m. Be to, 46 proc. sumažèjo hospitalizavimo dažnumas (nuo 71 iki 38) dèl paūmejjusios lètinès obstrukcinès plaučiuc ligos ir 62 proc. - ligoninèje praleistų dienu skaičius (nuo 1131 iki 432 dienų).

Vokietijoje atliktas tyrimas su sergančiais sunkia LOPL taip pat įrodè, kad sumažèjo hospitalizavimo dažnumas, be to, mažiau reikejjo trumpai veikiančiu beta 2 agonistu per dieną. 14-ai iš 26 pacientu buvo taikyta 18 ménesiu reabilitacija, ir, palyginti su kontroline grupe, reabilituoti ligoniai rečiau hospitalizuoti (3, palyginti su 14), vartojo mažiau trumpai veikiančių beta 2 agonistų per dieną (2,4, palyginti su 5,7 ịpurškimais per dieną).

Kito tyrimo tikslas buvo įrodyti, kad, taikant medikamentinị gydymą ir pulmonologinę reabilitaciją kartu, galima greičiau pasiekti geresnị $\mathrm{PaO}_{2}, \mathrm{PaCO}_{2}$, pagerinti fizinę būklę, sumažinti dusulị nei gydant vien vaistais Tirta 60 pacientuc, kurie suskirstyti i tris grupes pagal obstrukcijos sunkumo laipsni. Gydymas truko 21 dieną. Rezultatai rodo, kad visiems pacientams, kuriems buvo taikytas sudetinis gydymas, pagerejo $\mathrm{PaO}$ ir $\mathrm{PaCO}_{2}$ rodikliai, fizinio krūvio toleravimas pagal 6 minučių ejjimo méginị, sumažèjo dusulys.

\section{APIBENDRINIMAS}

Straipsnyje apžvelgtos naujausios pulmonologinès reabilitacijos tendencijos ir gairès reabilituojant lètine obstrukcine liga sergančius pacientus pasaulyje.

Pulmonologinè reabilitacija, taikoma lètine obstrukcine plaučių liga sergantiems ligoniams, pagerina fizinio krūvio toleravimą, ištvermę, kvėpavimo ir kitų periferinių raumenų darbą, gyvenimo kokybę, sumažina nerimą ir depresiją, susijusią su lètinèmis plaučių ligomis, taip pat pagerina pacientu psichosocialinę adaptaciją, sumažina hospitalizavimo atvejų ir ligoninejje praleistų dienų skaičių, pailgina pacientų gyvenimą, todèl naudinga ir ekonominiu požiūriu.

Pulmonologinè reabilitacija rekomenduojama visiems ligoniams, sergantiems lètine plaučių liga, apribojusia jų kasdienę veiklą. Daugiausia dėmesio skiriama kineziterapijai: kvejpavimo mankštoms bei pacientu treniravimui - periferiniu bei kvépavimo raumenu stiprinimui. LOPL ligoniams rekomenduojamos 2-6 ménesiu reabilitacijos programos, kuriu pagrindas fiziniai pratimai, atliekami po 2 valandas mažiausiai 3 kartus per savaitę. Kartu pacientai mokomi, suteikiama pagalba norintiems mesti rūkyti, kontroliuojamas svoris 2008 / Nr. 2 (4) ir keičiama mityba, taikoma ergoterapija bei psichosocialinès priemonès. Fizioterapijos procedūros (išskyrus elektrinę raumenų stimuliaciją) nėra efektyvios, todèl nerekomenduojamos.

Reabilitacija pasiektas būklès pagerẻjimas ilgainiui ima mažèti. Tačiau kol kas nėra efektyvios programos, kuri padètų išlaikyti reabilitacijos poveikị ilgesnị laiką. Todèl lètinèmis plaučių ligomis sergančius pacientus reikètuc skatinti nuolat (bent 2 ar 3 kartus per savaitę) aktyviai mankštintis.

Šiuo metu Lietuvoje vykdoma pulmonologinė reabilitacija nèra efektyvi ir neduoda norimų rezultatų, nes jos laikas per trumpas, nèra bendros efektyviai veikiančios pulmonologinès reabilitacijos programos, neskiriamas fizinis krūvis treniruojamuoju režimu.

Vis dèlto netolimoje ateityje tikimasi teigiamu poslinkiu formuojant nauja pulmonologinès reabilitacijos programos strategiją bei jos vykdymą Lietuvoje, siekiant pagerinti lètinemis plaučių ligomis sergančiu pacientu gyvenimo kokybę, palengvinti simptomus, skatinti fizini ir emocinį aktyvumą, spręsti psichosocialines problemas.

\section{PULMONARY REHABILITATION IN CHRONIC OBSTRUCTIVE PULMONARY DISEASE}

DOVILE் KRYŽIÜTĖ, JOLITA VEDRICKAITÉ
DEPARTMENT OF PULMONOLOGY AND IMMUNOLOGY
KAUNAS UNIVERSITY OF MEDICINE

Key words: Chronic Obstructive Pulmonary Disease (COPD, pulmonary rehabilitation, body mass index (BMI), exercise training

Summary. Since the last statements on pulmonary rehabilitation by the American Thoracic Society (ATS; 1999) and the European Respiratory Society (ERS; 1997), there have been numerous scientific advances both in our understanding of the systemic effects of chronic respiratory disease as well as the changes induced by the process of pulmonary rehabilitation. And the new document had been developed by an international committee and had been endorsed by both the ATS and the ERS in 2006. Individuals with chronic obstructive pulmonary disease (COPD) still comprise the largest proportion of those referred for pulmonary rehabilitation. Exercise intolerance is one of the main factors limiting participation in activities of daily living among individuals with COPD. The cardinal symptoms of chronic respiratory disease that limit exercise in most patients are dyspnea and/or fatique, which may result from ventilatory constraints, pulmonary gas exchange abnormalities, peripheral muscle dysfunction, cardiac dysfunction, or any combination of the above. Exercise training, widely regarded as the cornerstone of pulmonary rehabilitation is the best available means of improving muscle function in COPD and (probably) other chronic respiratory diseases. Pulmonary rehabilitation programs involve patient assessment, exercise training, education, nutritional intervention, and psychosocial support.

\section{LITERATŪRA}

1. Y. Lacasse et al. Pulmonary rehabilitation for chronic obstructive pulmonary disease (Cochrane Review). In: The Cochrane Library, Issue 3, 2002. Oxford.

2. Nici L Donner C., Wouters E, Zuwallack R Ambrosino N Bourbeau J. et al. American Thoracic Society/European Respiratory Society statement on pulmonary rehabilitation. Am. J. Respir. Crit. Care Med 2006; 173(12):1390-1413.

Kiti literatūros šaltiniai - redakcijoje (iš viso 12). 